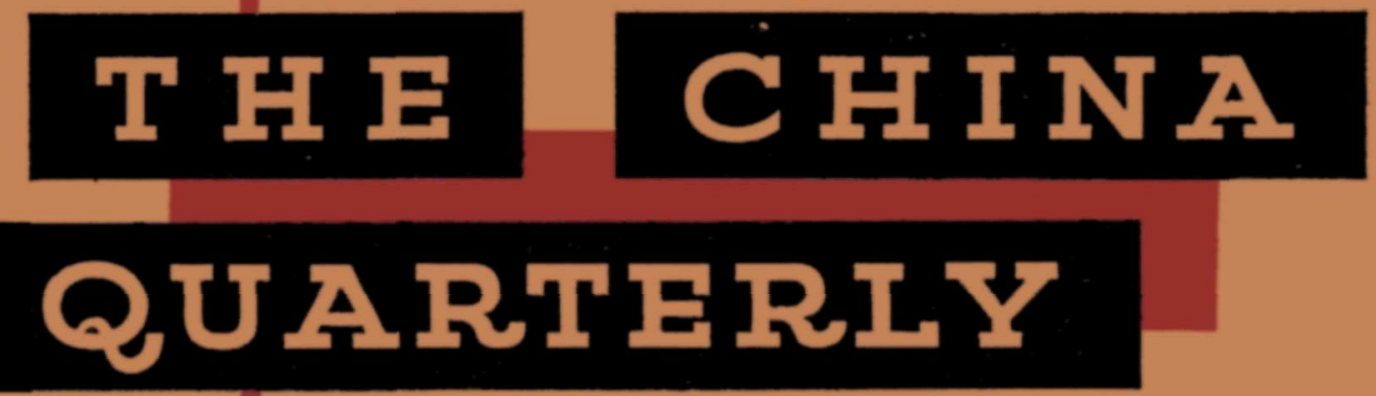

The Taxation System of the Shansi-

Chahar-Hopei Border Region, 1938-1945

Michael Lindsay

Economic Necessity and Political Ideals in Educational Reform during the Cultural Revolution Marianne Bastid

Industrial Production in Communist China:

1957-1968

Robert Michael Field

The Impact of the Cultural Revolution on China's Economic Elite

Richard K. Diao

The Red Guards and the World Student Movement Richard W. Wilson Amy A. Wilson

The Chinese Communist Youth Movement, 1949-66 Victor C. Funnell

\title{
COMMENT
}

BOOK REVIEWS

QUARTERLY CHRONICLE AND DOCUMENTATION

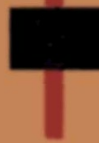




\section{Chan-Kuo Ts'e}

\section{Translated by}

\section{J. I. Crump}

This is the largest collection of pre-Han (c. $300-221$ B.C.) historical anecdotes, fables, and tales of great men. The Chinese have looked upon it for centuries as unreliable history and have condemned it for its offences against 'proper morality', but they have always admired its prose style and used it for a model. 1 map $£ 10$

Oxford Library of East Asian Literatures

\section{The Poetry of $\mathbf{T}^{\mathbf{6}}$ ao $\mathrm{Ch}^{\mathbf{6}}$ ien}

\section{Translated with commentary and annotation by}

\section{James Robert Hightower}

T'ao Ch'ien (or T'ao Yuan-ming), a philosophical poet of the early fifth century, was one of China's most highly esteemed writers, a man of principlo whose experience of officialdom led him to retire early to a life of hardship as a farmer rather than compromise his ideals. His poetry reflects the pleasures and trials of country living; this translation includes all his surviving work, with background information for the Western reader. $80 /-$ Oxford Library of East Asian Literatures

\section{While China Faced West}

\section{American Reformers in Nationalist China 1928-1937}

\section{James C. Thomson Jr.}

During the period covered by this book, the Nanking decade, the Chinese Nationalist government strove to build a new China with Western assistance. Mr Thomson describes how American missionaries and foundation representatives participated in the Nationalist attempt to transform rural society. $75 /-$ Harvard University Press

\section{A Study of Chinese Communes 1965}

\section{Shahid Javed Burki}

Communes have been the basic units of economic and political organization in rural China since 1958 . The author of this book, who in 1965 was allowed to study the communes, spent six weeks visiting them, holding discussions with their officials, and collecting data on their agricultural production. 34/- Harvard University Press

OXFORD UNIVERSITY PRESS 


\section{The China Quarterly}

an international journal for the study of China

April-June 1970

No. 42

The Taxation System of the Shansi-Chahar-Hopei

BORDER RegION, 1938-1945

Michael Lindsay 1

ECONOMIC NeCESSITY aNd POLITICAL Ideals

IN EDUCATIONAL ReFORM DURING THE

Cultural Revolution

Marianne Bastid 16

Industrial Production In COMmUnist

CHINA: 1957-1968

Robert Michael Field 46

The Impact of the Cultural Revolution on China's ECONOMIC Elite

Richard K. Diao 65

The Red Guards AND the World Student MOVEMENT

Richard W. and Amy A. Wilson 88

The Chinese Communist Youth

MOVEMENT 1949-1966

Victor C. Funnell 105

Comment: Otto Braun and the Tsunyi

Conference

Dieter Heinzig 131

New Chinese Grain Harvest Data

Werner Klatt 135

An Early Article by Lin Piao

Bruce J. Esposito 136

Book Reviews (for details see p. iii)

Book Notes

Correspondence

Quarterly Chronicle and Documentation (January-March 1970)

Contributors 


\section{THE CHINA QUARTERLY}

\section{Executive Editor}

David C. Wilson
Administrative Assistant

Angela Gibbs

\section{Editorial Board}

A. Doak Barnett, Brookings Institute; Cyril Birch, Berkeley; Howard L. Boorman, Vanderbilt; Jerome A. Cohen, Harvard Law School; Vidya Prakash Dutt, Delhi; Alexander Eckstein, University of Michigan; John K. Fairbank, Harvard; Albert Feuerwerker, University of Michigan; Herbert Franke, Munich; Maurice Freedman, ${ }^{*}$ London School of Economics; John Gittings, ${ }^{*}$ London School of Economics; A. M. Halpern, Harvard; G. F. Hudson, * St. Antony's College; Werner Klatt, St. Antony's College; Donald W. Klein, Columbia; John W. Lewis, Stanford; Choh-ming Li, Chinese University of Hong Kong; John M. H. Lindbeck, Columbia; Roderick MacFarquhar; Mark Mancall, Stanford; Yuji Muramatsu, Tokyo; C. H. G. Oldham,* Sussex; Dwight Perkins, Harvard; Lucian W. Pye, M.I.T.; Robert A. Scalapino, Berkeley; Stuart R. Schram,* School of Oriental and African Studies; Benjamin Schwartz, Harvard; G. William Skinner, Stanford; George E. Taylor, University of Washington; Kenneth R. Walker,* School of Oriental and African Studies; Wang Gungwu, Australian National University; Hellmut Wilhelm, University of Washington; William E. Willmott, British Columbia; Mary C. Wright, Yale.

- Members of Executtve Commitee.

\section{Editorial and Business Offices}

Contemporary China Institute, 24 Fitzroy Square, London W.1.

\section{Subscription Office}

Research Publications, 11 Nelson Road, London S.E.10.

\section{Subscription Rates}

$£ 3$ or U.S.\$7.50 per year, post free. Reduced rates for full-time students at $£ 2$ or U.S. $\$ 5$ per year. Individual copies, 15 shillings or U.S.\$2.00 for current and previous issue; otherwise $\mathrm{f1}$ or U.S.\$2.50. Special arrangements can be made for subscribers in areas with currency restrictions and for posting by airmail.

\section{Manuscripts}

The China Quarterly welcomes the submission of manuscripts on all aspects of contemporary China and from all points of view, including those which deal with Taiwan and Overseas Chinese. Articles on China prior to 1949 are also welcome, particularly, but not exclusively, when these relate directly to contemporary China or to the history of the Chinese Communist Party. Articles should be submitted, together with a duplicate copy, to the editorial office. They should be typed in double spacing and, preferably, conform to the styling of The China Quarterly.

The China Quarterly is published by the Contemporary China Institute of the School of Oriental and African Studies, London University, with the support of the International Association for Cultural Freedom. The views expressed in articles are those of individual authors and do not necessarily represent the views of the Contemporary China Institute. 


\title{
CONTENTS_continued
}

\section{Book Reviews}

Survey of the Sino-Soviet Dispute, 1963-1967. By John Gittings.

The Arms Race and Sino-Soviet Relations. By Walter C. Clemens, Jr.

William E. Griffith 138

Sun Yat-sen, His Life and Its Meaning. By Lyon Sharman.

Harold Z. Schiffrin 142

Nelson T. Johnson and American Policy Toward China, 1925-1941.

By Russel D. Buhite.

Tang Tsou 145

Modern China's Search for a Political Form. Edited by Jack Gray.

Mary C. Wright 148

The Comintern and the Chinese Communists, 1928-1931. By Richard C. Thornton.

Allen Whiting 149

La revolution culturelle vue par un sovietique. By A. Jelokhovtsev.

Rural Communes of China: Organizational Problems. By Gargi Dutt.

\author{
Alec Nove \\ Andrew Watson 151 \\ Subramanian Swamy 154
}

Industrial Development in pre-Communist China: A Quantitative Analysis.

By John K. Chang.

Ralph W. Huenemann 156

Mao Tse-tung in Selbstzeugnissen und Bilddokumenten. By Tilemann Grimm.

Herbert Franke 158

Peking and the New Left: At Home and Abroad. By Klaus Mehnert.

Richard W. Wilson 158

Whanghai Journal: An Eyewitness Account of the Cultural Revolution. By Neale Hunter.

Ray Wylie 159

Chinaköpfe: Kurzbiographien der Partei-und Staatsfunktionäare der Volksrepublik China. By Wolfgang Bartke.

China und die Barbaren. By Kuo Heng-yü.

Mao's Kulturrevolution: Analyse einer Karikatur. By Kuo Heng-yü.

Adrian Hsia 160 


\section{Modern China Studies International Bulletin}

a bi-annual Bulletin of post-graduate research in progress conferences and senior staff movements in the field of modern China studies, published by The China Quarterly

Issues $1 \& 2$ (August 1970 and Februrary 1971), to be issued free to China Quarterly subscribers, will provide a comprehensive survey of current research on 20th-century China.

The Bulletin will be put on a subscription basis with Issue 3, August 1971. From then on, the August issue will be devoted to news of conferences and senior staff movements in the year to come, while the February issue will list current post-graduate research projects.

The Assistant Editor, Mrs Jill Kitson, is collecting information about current research for inclusion in Issue 1. If you have not yet been contacted, please write as soon as possible with details of your project, set out as in the specimen entry, to:

Modern China Studies International Bulletin 37 Sidney Road, Twickenham, Middlesex, England

\section{Specimen entry:}

Other, A.N.

National University, Southern Province, Utopia, Dept. of Pol. Sci.

The inter-relationship between the central and provincial governments in China 1958-65

A study of the political and economic relations between the provinces and the centre, with particular reference to the southeast maritime provinces. Evidence from provincial newspapers and unofficial publications during the Cultural Revolution is used to argue that the degree of local independence from Peking was directly related to the grain surplus/deficit of individual provinces. edc (estimated date of completion) 1971.

Proposed annual subscription rates : $\$ 4$ or 33 s ( $£ 1.65$ ); to China Quarterly subscribers, $\$ 3$ or $25 s$ ( $€ 1.25$ )

Single copies: August issue, $\$ 1.50$ or $12 \mathrm{~s} 6 \mathrm{~d}(62 \mathrm{p})$; February issue, $\$ 4.50$ or $37 \mathrm{~s}$ ( $£ 1.85$ )

Subscription office: Research Publications, 11 Nelson Road, London, S.E. 10. 